\title{
Article \\ Origin of a Petrographic Coal Structure and Its Implication for Coalbed Methane Evaluation
}

\author{
Wei Cheng ${ }^{1,2,3} \mathbb{B}$, Ruidong Yang ${ }^{4, *}$ and Qin Zhang ${ }^{1,2,3}$ \\ 1 College of Mining, Guizhou University, Guiyang 550025, China; wcheng1@gzu.edu.cn (W.C.); \\ qzhang@gzu.edu.cn (Q.Z.) \\ 2 National \& Local Joint Laboratory of Engineering for Effective Utilization of Regional Mineral Resources \\ from Karst Areas, Guiyang 550025, China \\ 3 Guizhou Key Laboratory of Comprehensive Utilization of Non-Metallic Mineral Resources, \\ Guiyang 550025, China \\ 4 College of Resources and Environmental Engineering, Guizhou University, Guiyang 550025, China \\ * Correspondence: rdyang@gzu.edu.cn; Tel.: +86-851-8362-0551
}

Received: 18 May 2020; Accepted: 10 June 2020; Published: 16 June 2020

\begin{abstract}
A petrographic coal structure of Late Permian coals from the Liupanshui coalfield, Western Guizhou, SW China, has been distinguished for its novel macro-lithological characteristics. Petrographic, mineralogical and geochemical studies have been conducted for a typical coal sample (No.3 coal, Songhe coalmine, Panzhou County, China) and its geological genesis and significance for coalbed methane (CBM) evaluation is accordingly discussed. It was found that coal is characterized by a banded structure with intensively fractured vitrain sublayers, where a great number of fractures were developed and filled with massive inorganic matter. The study of coal quality, coal petrography, mineralogy and lanthanides and yttrium (REY) geochemistry of the infilling mineral matter (IMM) indicates that this fractured coal structure resulted from the tissues of coal-forming plants or coal matrix shrinkage, as well as the precipitation of calcium rich groundwater and the addition of terrigenous materials. The coal depositional environment and coal-forming plant are considered to have played a role in inducing the special fractures. This provides a scientific reference for the study of CBM for coal with this fractured structure, such as the Late Permian coal from the western border of Guizhou Province, SW China.
\end{abstract}

Keywords: coal; petrography; structure; coalbed methane

\section{Introduction}

Coal is a combustible organic rock composed of both organic and inorganic matter [1], where the former is generally interpreted as being formed from plant residual material through complicated biological, physical and chemical processes [2-4]. Unlike other rocks, coal is characterized by its porous structure matrix that is intersected by many cleats, fractures, mineral matters and residuals of coal-forming plants [5], which can be mainly attributed to the impact of stress fields, degrees of alteration, petrologic types, vitrinite contents, and mineral infilling [6,7].

Coalbed methane (CBM), also known as coalbed gas, has been considered to be a hazard due to gas outbursts and explosions during coal mining processes for over a century [8]. Researchers found that the characteristics of the structure of coal are of great significance for the occurrence and flow status of $\mathrm{CBM}$, and it is thus crucial to improve safety conditions in coal mining [9-11]. CBM is now considered to be both a hazardous gas, and also a resource commodity in terms of commercial exploitation of CBM deposits. In fact, CBM has been commercially extracted in many countries, mainly Australia, Canada, China, India, Poland and the USA [11]. According to statistical data [12], the geological resources of 
CBM with a depth of less than $2000 \mathrm{~m}$ in China amount to about 30 trillion cubic meters. A number of authors stated that the prerequisite to obtain economically and technically viable projects in CBM recovery, as well as in the prevention of coal mine methane-related disasters, was intimately related to coal permeability, which depends on coal fracturing (such as the fracture spacing, length, height, connectivity, aperture size and degree of mineral infilling) [7,10,13-18].

The term "cleat" was first used in 1925 as the general designation for a variety of fractures in coal [9]. However, cleat in coal is more often understood as jointing in competent rocks, which is the result of shrinkage occurring during the process of coalification, stress release, and extensional strain [19]. Rodrigus [10] confirmed that the cleat system could be theoretically characterized by two main sets of sub-parallel fractures, namely the "face cleat" and "butt cleat", and both are mostly orthogonal to bedding [5]. Since the coal fractures discussed in this paper do not have rock-joints-like morphological features, as described above, the term "fracture", instead of "cleat", is used in the following discussion.

Apart from large-scale faults and joints, the opening-mode small-scale or micro-scale fractures are also well developed in coal. These fractures usually cannot cross different lithotypes (such as vitrain, clarain, durain and fusain) [9], which has been recognized by previous studies. Weniger suggested that bright lithotypes tend to be more highly fractured than dull lithotypes [18]; here, the bright lithotype refers to vitrain, while dull lithotype consists of clarain, durain or fusain. Su [14] and Cheng [16] confirmed that the vitrain layer tends to develop intensive endogenetic fractures. In addition, some other previous studies also revealed that, during diagenetic and epigenetic stages, authigenic minerals may appear in the fracture walls $[5,6,20]$, and the properties of those infilling mineral matter (IMM) in the fractures were investigated and some encouraging results were obtained to better understand the elemental and mineralogical anomalies in coal [21-24].

According to "China Mineral Resources 2019", released by Ministry of Natural Resources, People's Republic of China [12], China held an estimated 1709 Gt of identified coal reserves, the third largest in the world, behind the United States and Russia. Guizhou Province of SW China, known as the "coal sea in South China", has identified coal resources of 75 Gt (mainly Late Permian coal), ranking fifth in the country [25]. However, frequently occurring safety accidents, e.g., CBM outbursts and explosions, have been a prominent problem encountered in the coal industry in the region. As mentioned above, understanding the coal fracture features is of great significance for predicting the occurrence modes and flow features of CBM, which is crucial for both coalbed methane accident prevention and gas extraction [18]. In this study, petrographic, mineralogical and geochemical studies were conducted for a Late Permian coal site, and the results might provide a valuable reference to better understand the genesis of coal fractures, thereby providing a scientific reference for CBM study.

\section{Geological Settings}

Western Guizhou was a part of a stable intra-cratonic basin within the west margin of the Yangtze Block during the Late Paleozoic, situated between the Khangdian upland to the west and the Cathaysian landmass to the east [26,27]. It has been interpreted that the geological evolution of Western Guizhou was accompanied by multi-stage tectonic movements [28]. Intensive volcanic activity, known as the "Emei Mantle Plume", occurred in the Mid-Late Permian, leaving not only extremely thick basalt over the Kangdian upland, but also causing rock mass (dolerite) intrusion and hydrothermal activities, thus resulting in a relatively complicated geological setting for coal accumulation. Since Western Guizhou is located in the east side of the Khangdian upland, it is the weathered products of Emeishan basalts that provide major terrestrial-derived clastic material for coal basins in the east (Figure 1). The multi-stage tectonic movements triggered magma and low-temperature hydrothermal activities, which also contributed to inorganic impurities in the Late Permian coal. As stated by Dai [29], source rock, volcanic ash, low-temperature hydrothermal fluid, groundwater, and magmatic hydrothermal inputs were important factors for the geochemical and mineralogical anomalies of coals in Western Guizhou. 
With the rise of the Emei mantle-plume in Late Permian, seawater entered Guizhou from the SE to NW. The transgression and regression of the seawater formed a wide transitional zone between the land and sea, which provided favorable conditions for peat accumulation. As a result, the Late Permian paleogeography in Western Guizhou varied, generally from NW to SE, from alluvial and fluvial plains, via rivers, deltas and tidal flats to shallow marines (carbonate platform) and abyssal basins $[27,29,30]$. Terrestrial and paralic coal measures were widely developed in the Late Permian coal-bearing strata, which was subdivided into Longtan Formation (equivalent of Wuchiapingian) and Changxing Formation (Changhsingian).

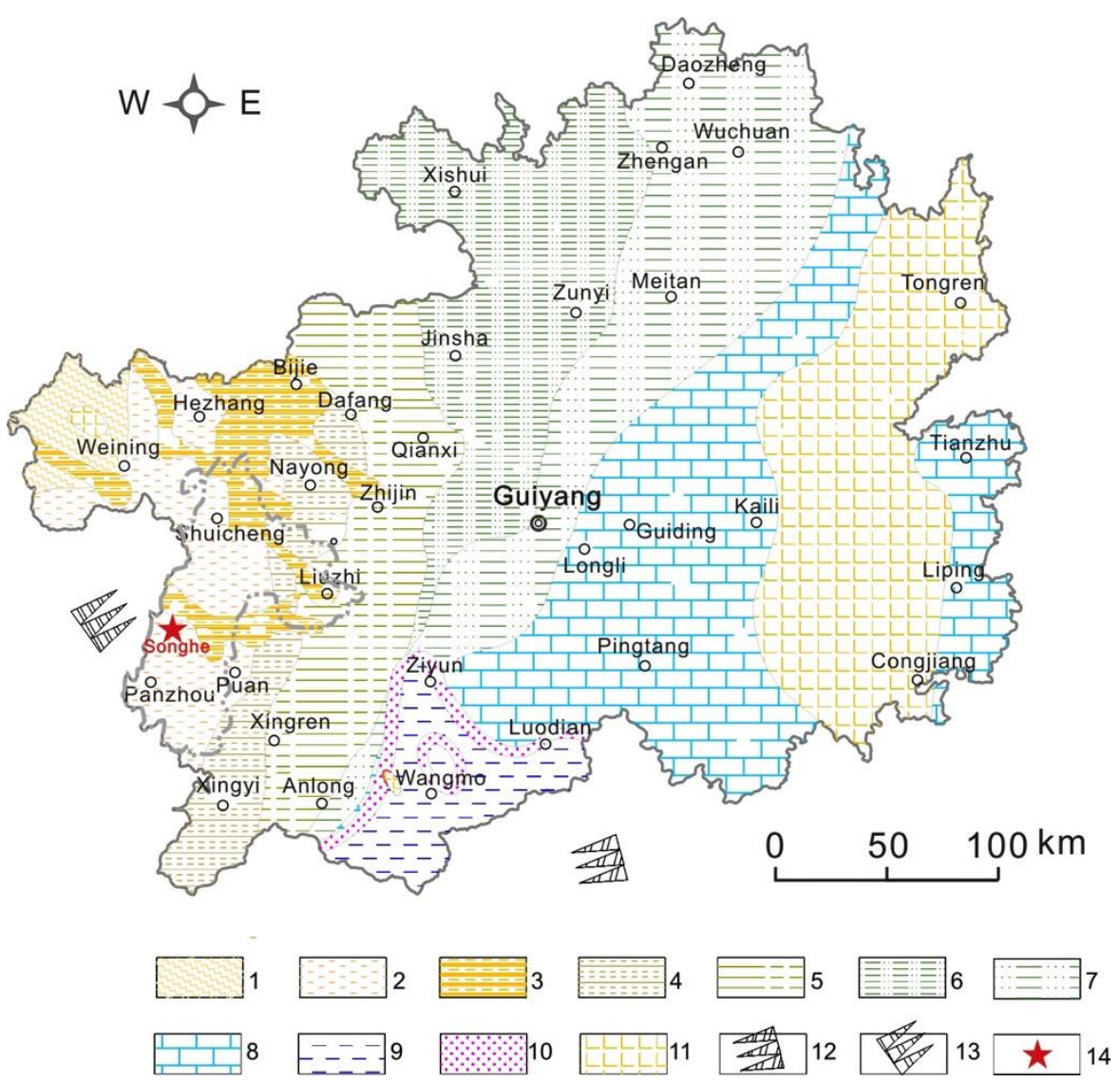

Figure 1. Late Permian paleogeography of Guizhou Province, Southwestern China (modified from Guizhou Bureau of Geology and Mineral Exploration, 1987 [31]). 1-river; 2-river dominated upper delta plain; 3-distributary channel; 4-transitional delta (interdistributary bay); 5-tide dominated lower delta plain; 6-tidal flat and lagoon; 7-restricted platform; 8-open platform; 9-deep basin; 10-reef limestone; 11-upland; 12-terrigenous direction; 13-transgression direction; 14-sampling location.

\section{Samples and Analysis Methods}

A representative coal sample from No.3 coal seam of the Songhe coalmine, Panzhou mining area of Western Guizhou (as the red star marked in Figure 1), was selected as the object for a detailed study and the results are presented in this paper. Proximate analysis and sulfur content determination were conducted according to Chinese standards GB/T 212-2008 (based on international standard ISO 11722:1999) [32] and GB/T 214-2007 (based on international standard ISO 334:1992, ISO 351:1996) [33], respectively. The method of microscopically determining the maximum reflectance of vitrinite $\left(\mathrm{Ro}_{\max }\right)$ was GB/T 6948-2008 (based on international standard ISO 7404-5:1994) [34] with an optical thin slice of the coal sample, which was made according to GB/T 16773-2008 (based on international standard ISO 7404-2:1985) [35]. Polished thin sections of the vitrain layers of bulk samples were made to 
investigate the microstructure and mineral components by using both an optical microscope (Olympus, Tokyo, Japan, CX21) and SEM-EDS (S-3400N, HITACHI, Tokyo, Japan,) in the National and Local Joint Laboratory of Engineering for Effective Utilization of Regional Mineral Resources from Karst Areas, and Analysis Center of Guizhou University, respectively. Specifically, polished thin sections of the vitrain layers were made by the following steps: first, the coal sample is wrapped with gauze to avoid breaking, then immersed in binder (mixture of rosin and paraffin wax) and heated at less than $130{ }^{\circ} \mathrm{C}$ until the bubbles no longer occur. After stopping heating, wait 10 min before removing the coal sample. A coal block $(40 \times 25 \times 15 \mathrm{~mm})$ is obtained by cutting the treated sample, and finally a polished thin section is obtained through coarse grinding, fine grinding and polishing.

The IMM was extracted manually and ground into a fine powder (particle size less than $0.075 \mathrm{~mm}$ ) for trace elements analysis by ICP-MS (ELAN DRC-e, Perkin Elmer, Waltham, MA, USA), and mineral contents determination by XRD, which were conducted in the State Key Laboratory of Ore Deposit Geochemistry, Institute of Geochemistry of Chinese Academy of Sciences. As for the trace elements analysis, the following procedures were applied: $50 \mathrm{mg}$ of the sample is calcined at $750{ }^{\circ} \mathrm{C}$ for $2 \mathrm{~h}$ and put into a PTEF crucible, together with $1 \mathrm{~mL} \mathrm{HF}$ and $1 \mathrm{~mL} \mathrm{HNO}_{3}$, sealed in a steel bushing and kept in an oven at $190{ }^{\circ} \mathrm{C}$ for $36 \mathrm{~h}$, then cooled and evaporated until dry, with $1 \mathrm{~mL} \mathrm{HNO}_{3}$ added and dried again. After that, $500 \mathrm{ng} \mathrm{Rh}$ (interior label), $2 \mathrm{~mL} \mathrm{HNO}_{3}$ and $3 \mathrm{~mL}$ deionized water was added into the crucible and placed into the steel bushing again and heated at $140{ }^{\circ} \mathrm{C}$ for $5 \mathrm{~h}$, then cooled and diluted-it was then ready for testing. The relative standard deviation was less than $10 \%$. XRD patterns were collected on a Panalytical multifunction X-ray diffractometer equipped with a 3D PIXcel detector (model: Empyrean, PANalytical, Eindhoven, The Netherlands). The XRD measurement was performed in the $2 \theta$ range of $5-80^{\circ}$, in the mode of continuous scanning with $0.026^{\circ}$ in step size and counting time of $30 \mathrm{~s}$ per step. The working voltage and current were $40 \mathrm{kV}$ and $40 \mathrm{~mA}$, respectively.

Specifically, the separation process of vitrain layers and IMM from bulk coal is as follows: first, select a bulk coal sample which has two exposed vitrain layers on both sides (the bottom and the top side), then strip the two vitrain layers with a knife. A vitrain layer sample is obtained through the coning and quartering method. The rest, which contains no vitrain layer, is thus considered to be the "other parts", in addition to the vitrain layer. Proximate analysis, sulfur content and Romax determination are conducted for the sample of vitrain layers and the sample of other parts, respectively. IMM particles are collected from the separated vitrain layer sample with a medical tweezer. About $5 \mathrm{~g}$ of IMM was obtained and ground into powder with a particle size of less than $0.075 \mathrm{~mm}$ for XRD and ICP-MS analysis.

\section{Results and Discussion}

\subsection{Morphology of the Fractures}

As shown in Figures 2 and 3, the coal has a banded structure, and it was found that the vitrain sublayers developed intensive fractures that were filled with mineral matters. It is notable that on the bedding surface of the vitrain sublayer, most of the fractures are extending, forking or intersecting with each other, displaying plant-tissue-like patterns. It is not uncommon for coal fractures to be filled with mineral matters; for example, Dai [22] studied coal from Yili Basin, northwestern China, and found that micro-scale dendritic fractures were filled with massive mineral matters. However, coals investigated in this study display a morphology of plant tissue, and there is still little attention paid to the details of these plant-tissues-like fractures, as well as the property of the IMM and their geologic origin. 

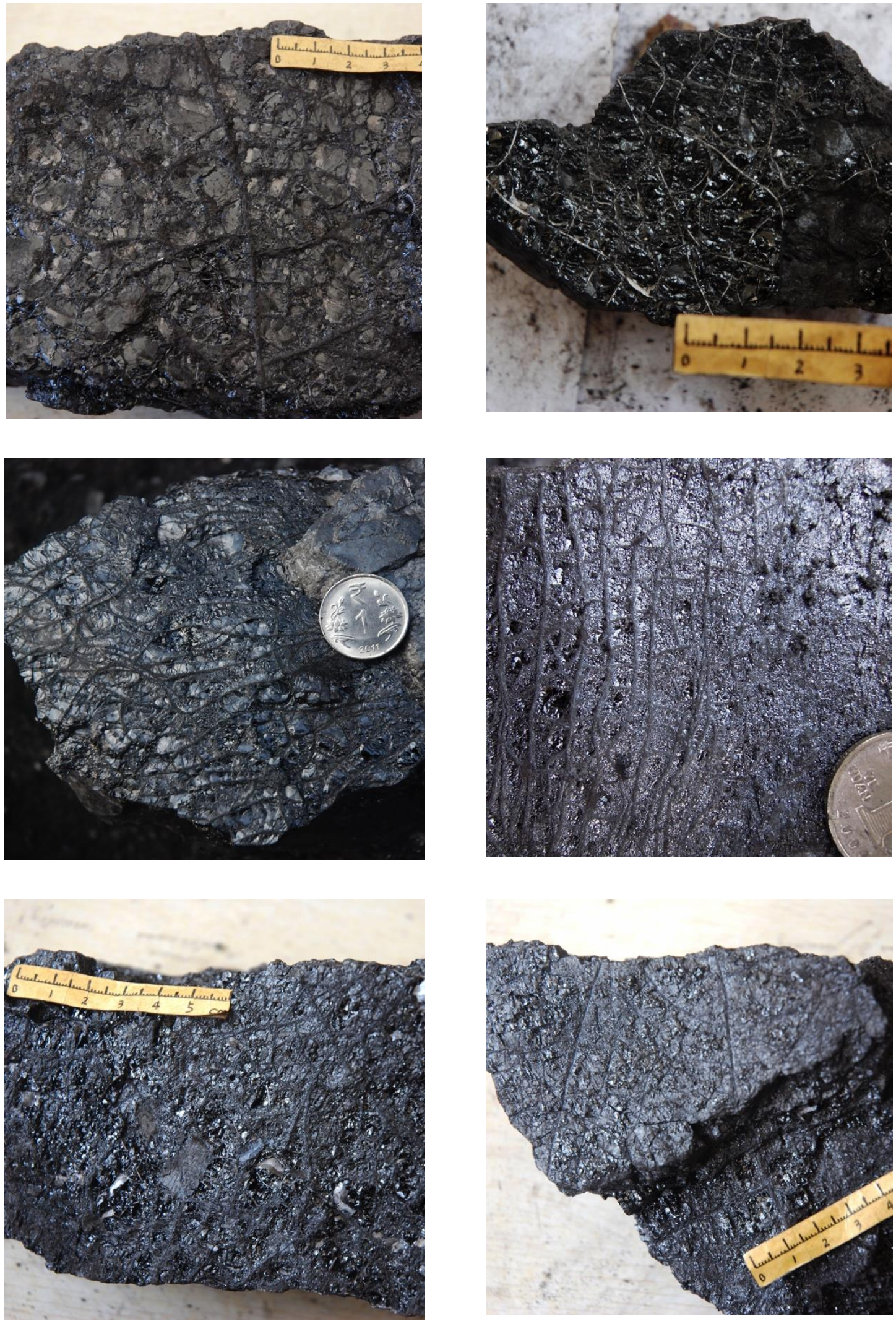

Figure 2. Photographs of the bedding surfaces of cleated structural coals, from Western Guizhou and eastern Yunnan, Southwestern China. 


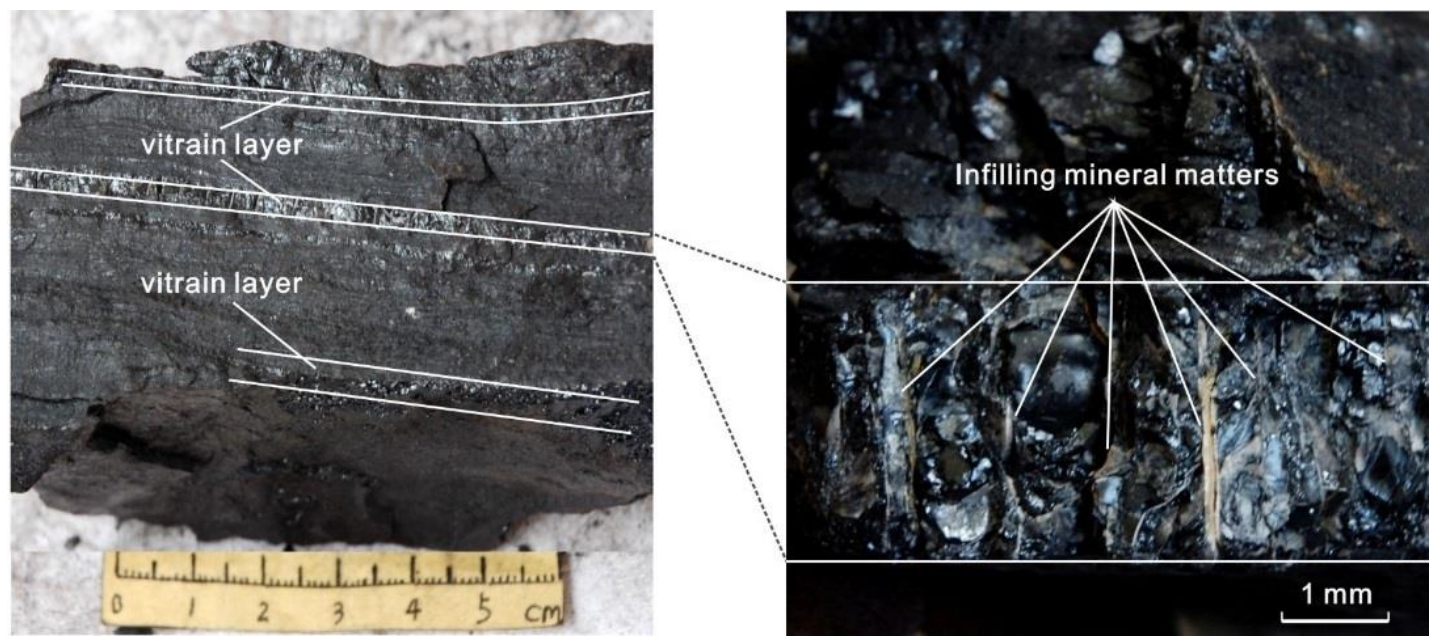

Figure 3. Photographs of coal structure (lateral section) with banded vitrain layers filled with mineral matter, No.3 coal from Songhe coalmine, Liupanshui coalfield of Southwestern China.

At first glance, the fractures run randomly, however, all the fractures show a certain regularity, most of which are either "mainstream" fractures or "branch" fractures. In other words, fractures can be identified as either trunk fractures with an average width of $0.5-1.0 \mathrm{~mm}$ or subordinate fractures with an average width of less than $0.2-0.3 \mathrm{~mm}$, which form branches of the trunks. An optical microscope with reflected light was used to study the nature of the fractures (Figure 4). On a microscopic scale, the fractures show similar characteristics as they are observed by the eyes. That is, each of them grows out of smaller fractures, with fractal characteristics like that of leaf veins and plant roots. Overall, those fractures present an image that grows naturally and gradually, rather than cutting or running through the coal accidentally.
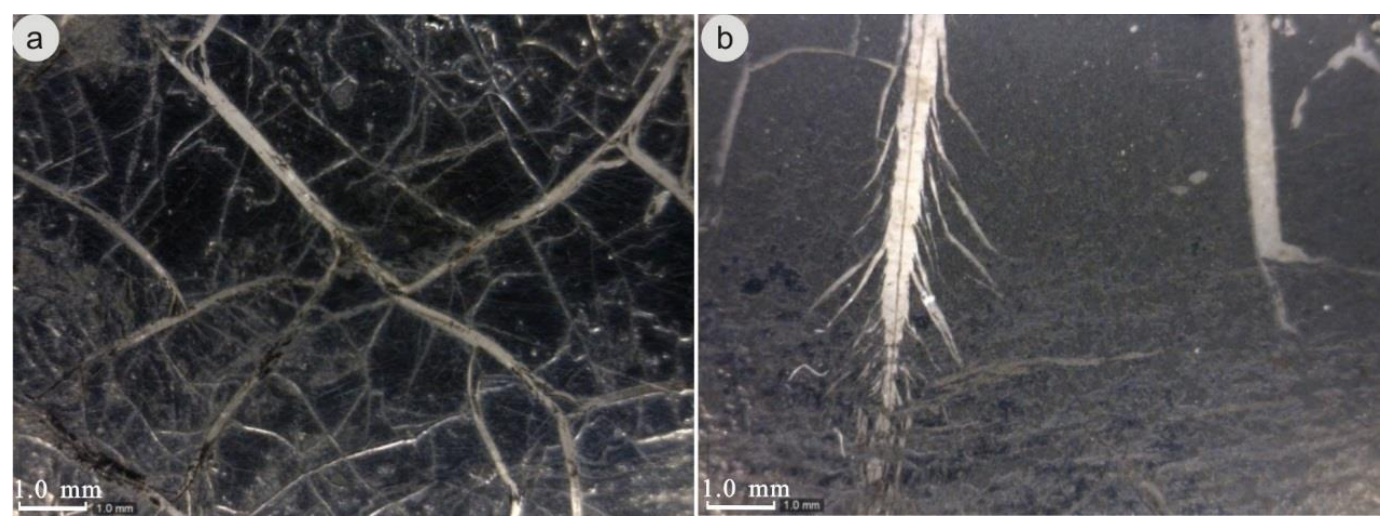

Figure 4. Photomicrographs of fractures in the vitrain layer (reflected light), No.3 coal of Songhe coalmine, Liupanshui coalfield, Southwestern China. (a): leaf vein-like infilled fractures; (b): root-like infilled fractures.

\subsection{Coal Quality and Petrology}

Coal lithotypes include vitrain, clarain, durain and fusain, and vitrain has the highest glossiness and can be easily distinguished in banded structural coals [6]. Since the fractures only develop in the vitrain layers, coal quality tests were conducted individually for the vitrain layers and other parts (clarain, durain and fusain as a whole). As shown in Table 1, the vitrain layers and other parts of the coal are similar in terms of moisture content, total sulfur content and the maximum reflectance of vitrinite $\left(\operatorname{Ro}_{\max }\right)$. The dried basis volatile of the vitrain layer sample is much higher than other parts of the coal, which is in accordance with the common conclusion that vitrain has the highest volatiles 
and strongest viscidity among all the four coal lithotypes [6]. However, the vitrain layer sample was unexpectedly found to have a remarkably lower ash yield than the other parts of the coal.

Table 1. Values of coal quality and maximum reflectance of vitrinite of coal with cleated structures from the Songhe coalmine, Liupanshui coalfield, Southwestern China.

\begin{tabular}{cccccc}
\hline Samples & $\mathbf{M}_{\mathbf{a d}}, \boldsymbol{\%}$ & $\mathbf{A}_{\mathbf{a d}}, \boldsymbol{\%}$ & $\mathbf{S}_{\mathbf{t}, \mathbf{d}, \boldsymbol{\%}}$ & $\mathbf{V}_{\mathbf{a d}}, \boldsymbol{\%}$ & $\mathbf{R}_{\mathbf{o m a x}}, \boldsymbol{\%}$ \\
\hline Vitrain layers & 1.12 & 21.07 & 0.11 & 38.50 & 1.14 \\
Other parts & 1.20 & 27.87 & 0.11 & 26.11 & 1.16
\end{tabular}

Note: $\mathrm{M}_{\mathrm{ad}}$ —air-dried moisture content, $\mathrm{A}_{\mathrm{ad}}$ —air-dried basis ash yield, $\mathrm{V}_{\mathrm{ad}}$ 一air-dried basis volatiles, $\mathrm{S}_{\mathrm{t}, \mathrm{d}}$ —air-dried basis total sulfur content, $R_{o m a x}$-maximum reflectance of vitrinite.

\subsection{Mineralogy and Geochemistry of the IMM}

A mineralogy study on IMM was conducted using optical microscopy identification, XRD and SEM-EDS. An XRD study shows that the IMM primarily consists of calcite (98.51\%), and a small amount of quartz, dolomite and clay, such as kaolinite. Optical microscope identification and SEM-EDS analysis provides more evidence of the mineralogical features of the IMM. It was found that the IMM is dominated by calcite, most of which occurs in the shape of branches or roots (Figure 5). The mineral veins show numerous ragged or twisted fractures, implying that the coal might have experienced slight physical transformation during the formation of the IMM. As shown in Figure 6, chemical compositions of the three spots are determined by SEM-EDS and the result shows that they are dominated by $\mathrm{Ca}$, $\mathrm{C}$, and $\mathrm{O}$. For example, the mass percent concentration of $\mathrm{Ca}, \mathrm{C}$ and $\mathrm{O}$ of the spot in Figure 6a are $38.5 \%, 18.1 \%$ and $36.4 \%$, respectively. According to the concentration of $\mathrm{Ca}$, the theoretical content of calcite was calculated as 73.1\% because the mass ration of $\mathrm{Ca}, \mathrm{C}$ and $\mathrm{O}$ in pure calcite is 1:0.3:0.6. While for the spots in Figure $6 \mathrm{~b}, \mathrm{c}$, the theoretical content of calcite is $70.0 \%$ and $78.2 \%$, respectively. While the theoretical calculation data are somewhat different from the XRD test results, it can basically confirm that calcite is dominant in IMM.

Lanthanides and yttrium (abbreviated as REY) have gained relatively great attention in coal geology research for many years as they can be considered to be provenance indications for the sedimentary environment and inorganic matters in coal [36-42]. Therefore, the concentration and distribution pattern of the REY of the IMM and the IMM-free Songhe coal were studied to determine the genesis of the fractures. Besides, for comparison, the concentrations and distribution patterns of REY of the average Liupanshui coal (based on 155 samples from Liupanshui coalfield [43]) and the average of Emeishan basalt (based on 18 samples from Shuicheng, Liupanshui [44]) were also investigated. This is because the No.3 Songhe coal was sampled from Panzhou, which is a part of the Liupanshui coalfield of western Guzihou, and the Emeishan basalt derived from the Kangdian Upland has been considered as the primary terrigenous input into the Late Permian coal-forming environment $[27,29,43,45-47]$.

As shown in Table 2, IMM has a relatively high REY concentration of $412.4 \mu \mathrm{g} / \mathrm{g}$, which is much higher than the IMM-free Songhe coal $(56.8 \mu \mathrm{g} / \mathrm{g})$ and the average Liupanshui coal $(95.1 \mu \mathrm{g} / \mathrm{g})$, and is also much higher than the Emeishan basalt $(321.8 \mu \mathrm{g} / \mathrm{g})$, indicating an abnormal enrichment of REY in the IMM of the investigated coal. To better understand the origin of the IMM in coal, the upper continental crust (UCC) [48], rather than chondrite, is selected as a standard value for normalization of REY in coal because the former is sedimentary rock that has a similar genetic origin to coal $[40,41]$.

As shown in Figure 7, the UCC normalized pattern of REY in the IMM is characterized by a pronounced left incline with a $\mathrm{La}_{\mathrm{N}} / \mathrm{Lu}_{\mathrm{N}}$ value of 0.11 . The curve also shows an obvious Eu depletion $\left(\delta_{\mathrm{Eu}} 0.64\right)$ and slight Ce depletion $\left(\delta_{\mathrm{Ce}} 0.95\right)$. Similarly, in the case of the IMM-free Songhe coal, a left incline pattern is also observed, in both $\mathrm{La}_{\mathrm{N}} / \mathrm{Lu}_{\mathrm{N}}$, at 0.48 , and an obvious Eu depletion $\left(\delta_{\mathrm{Eu}}=0.80\right)$; however, no $\mathrm{Ce}$ anomalies are found as $\delta_{\mathrm{Ce}}=1.00$. While for the Liupanshui coal, the REY distribution pattern is of normal type, showing slightly weak light rare earth elements $(\mathrm{LREY})\left(\mathrm{La}_{\mathrm{N}} / \mathrm{Lu}_{\mathrm{N}}=0.82\right)$, and negative $\mathrm{Ce}$ and $\mathrm{Eu}$ anomalies $\left(\delta_{\mathrm{Ce}}=0.90, \delta_{\mathrm{Eu}}=0.95\right)$. The REY distribution pattern of the Emeishan basalt is of M-type $\left(\mathrm{La}_{N} / \mathrm{Sm}_{\mathrm{N}}=0.58<1, \mathrm{Gd}_{\mathrm{N}} / \mathrm{Lu}_{\mathrm{N}}=1.69>1\right)$, which is distinct in characteristics from 
that of the samples mentioned above. In addition, the curve exhibits negative Ce anomalies $\left(\delta_{\mathrm{Ce}}=0.94\right)$ and strong positive Eu anomalies $\left(\delta_{\mathrm{Eu}}=1.55\right)$.
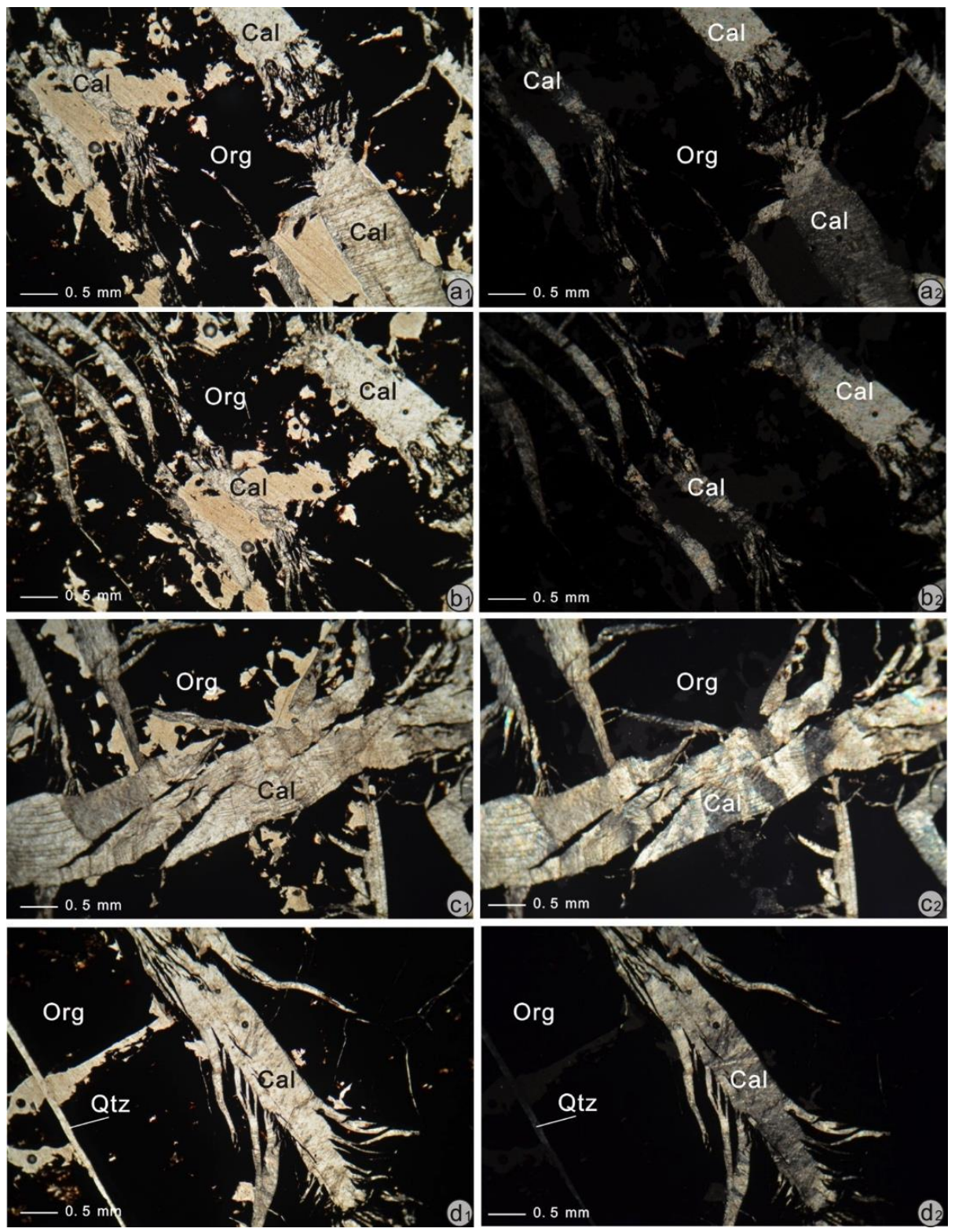

Figure 5. Vein-like calcite and quartz of the infilling mineral matter (IMM) under polarized light $\left(\mathbf{a}_{1}, \mathbf{b}_{1}, \mathbf{c}_{1}, \mathbf{d}_{1}\right)$ and crossed polarizer light $\left(\mathbf{a}_{2}, \mathbf{b}_{2}, \mathbf{c}_{2}, \mathbf{d}_{2}\right)$ of cleated structural coal from the No.3 coal seam, Songhe coalmine, Liupanshui coalfield. Abbreviation: Cal—Calcite, Qtz-Quartz, Org-Organic matter.

Cerium and europium in coal mainly displays negative, weakly negative, or no anomalies [41]. The Liupanshui coal, the IMM and the IMM-free Songhe coal show weakly negative or no Ce anomalies (Table 2), and this may be related to the weakly negative Ce anomalies of the Emeishan basalt in the sediment source region [41,49]. However, previous studies suggested that silicic volcanic rock detrital [47] and felsic or felsic-intermediate rocks [23] from the Kangdian Upland may also provide terrigenous materials for the Late Permian coal-bearing strata in SW China and influence the REY in coal, although they are not dominant contributors. Surface water, which has negative or strongly negative Ce anomalies, probably played a role in the REY fraction in coal [50]. 

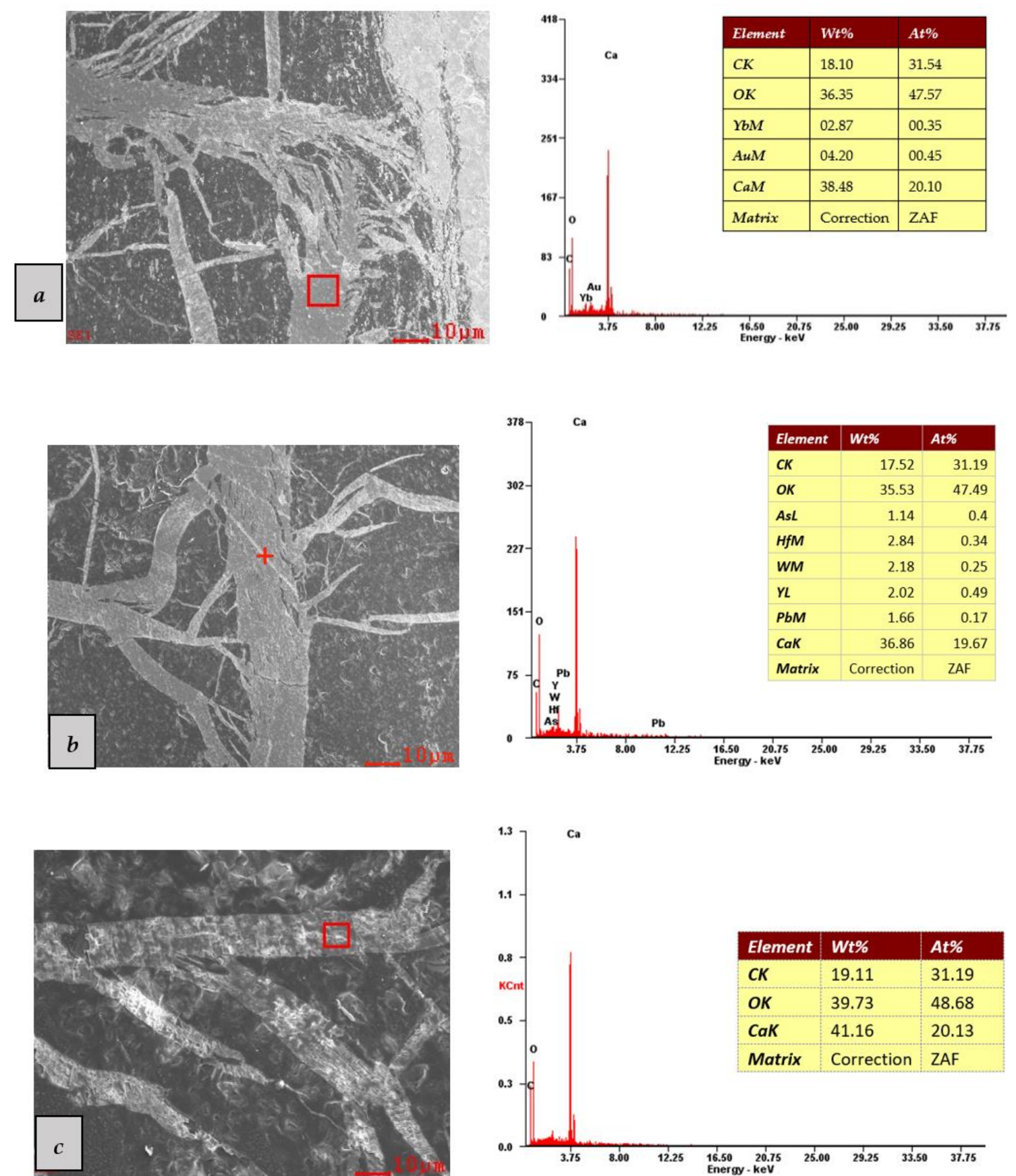

Figure 6. Results of SEM-EDS analysis of the infilling mineral matter (IMM) of the cleated structure coal from the Songhe coalmine, Liupanshui coalfield, Southwestern China. Note: Red crosses and red boxes in the picture are the detecting spots or areas of minerals. (a): Veined calcite with a ragged or twisted pattern; (b): Intersecting calcite vein; (c): Veined calcite with a root-like pattern. 
Table 2. Rare earth elements concentration and characteristic values of the IMM of fracture- structural coal, the IMM-free Songhe coal, the Liupanshui coal and the Emeishan basalt, Western Guizhou, Southwestern China $(\mu \mathrm{g} / \mathrm{g})$.

\begin{tabular}{|c|c|c|c|c|c|c|c|c|c|c|c|c|c|c|c|}
\hline Samples & La & $\mathrm{Ce}$ & Pr & $\mathrm{Nd}$ & Sm & Eu & Gd & $\mathbf{T b}$ & Dy & $\mathbf{Y}$ & Ho & Er & $\operatorname{Tm}$ & $\mathbf{Y b}$ & Lu \\
\hline IMM & 28.70 & 61.70 & 7.61 & 32.00 & 10.10 & 1.77 & 15.36 & 3.53 & 29.80 & 174.00 & 6.17 & 18.20 & 2.74 & 17.90 & 2.87 \\
\hline IMM-free Songhe Coal & 7.67 & 17.20 & 1.98 & 7.73 & 1.70 & 0.30 & 1.77 & 0.28 & 2.02 & 13.00 & 0.43 & 1.21 & 0.18 & 1.17 & 0.17 \\
\hline Liupanshui coal & 16.92 & 31.29 & 3.68 & 13.98 & 2.82 & 0.55 & 2.64 & 0.43 & 2.63 & 16.10 & 0.54 & 1.58 & 0.23 & 1.44 & 0.22 \\
\hline Emeishan basalt & 42.30 & 81.40 & 10.90 & 43.50 & 8.87 & 2.72 & 7.79 & 1.17 & 6.61 & 36.90 & 1.30 & 3.57 & 0.52 & 3.08 & 0.51 \\
\hline Samples & \multicolumn{2}{|c|}{$\sum$ REY } & \multicolumn{2}{|c|}{ LREY } & \multicolumn{2}{|c|}{ MREY } & \multicolumn{2}{|c|}{ HREY } & \multicolumn{2}{|c|}{$\mathrm{La}_{\mathbf{N}} / \mathrm{Lu}_{\mathbf{N}}$} & $\delta \mathrm{Ce}$ & \multicolumn{2}{|c|}{$\delta \mathrm{Eu}$} & \multicolumn{2}{|c|}{$\mathrm{Y}_{\mathrm{N}} / \mathrm{Ho}_{\mathrm{N}}$} \\
\hline $\mathrm{IMM}$ & \multicolumn{2}{|c|}{412.44} & \multicolumn{2}{|c|}{140.11} & \multicolumn{2}{|c|}{224.45} & \multicolumn{2}{|c|}{47.88} & \multicolumn{2}{|c|}{0.11} & 0.95 & \multicolumn{2}{|c|}{0.64} & \multicolumn{2}{|c|}{1.03} \\
\hline IMM-free Songhe Coal & \multicolumn{2}{|c|}{56.81} & \multicolumn{2}{|c|}{36.28} & \multicolumn{2}{|c|}{17.37} & \multicolumn{2}{|c|}{3.16} & \multicolumn{2}{|c|}{0.48} & 1.00 & \multicolumn{2}{|c|}{0.80} & \multicolumn{2}{|c|}{1.10} \\
\hline Liupanshui coal & \multirow{2}{*}{\multicolumn{2}{|c|}{$\begin{array}{c}95.06 \\
321.76\end{array}$}} & \multicolumn{2}{|c|}{68.69} & \multicolumn{2}{|c|}{22.35} & \multicolumn{2}{|c|}{4.01} & \multicolumn{2}{|c|}{0.82} & 0.90 & \multicolumn{2}{|c|}{0.95} & \multicolumn{2}{|c|}{0.98} \\
\hline Emeishan basalt & & & \multicolumn{2}{|c|}{244.40} & \multicolumn{2}{|c|}{66.24} & \multicolumn{2}{|c|}{10.58} & \multicolumn{2}{|c|}{0.94} & 0.94 & \multicolumn{2}{|c|}{1.55} & \multicolumn{2}{|c|}{0.88} \\
\hline
\end{tabular}

Note: $\sum$ REY is the sum of all rare earth elements $(\mathrm{La} \sim \mathrm{Lu}), \mathrm{LREY}=\Sigma(\mathrm{La}+\mathrm{Ce}+\mathrm{Pr}+\mathrm{Nd}+\mathrm{Sm}) ; \mathrm{MREY}=\Sigma(\mathrm{Eu}+\mathrm{Gd}+\mathrm{Tb}+\mathrm{Dy}+\mathrm{Y}) ; \mathrm{HREY}=\Sigma(\mathrm{Ho}+\mathrm{Er}+\mathrm{Tm}+\mathrm{Yb}+\mathrm{Lu}), \delta \mathrm{Ce}=\mathrm{Ce} /(0.5$ $\left.\times \mathrm{La}_{\mathrm{N}}+0.5 \times \mathrm{Pr}_{\mathrm{N}}\right) ; \delta \mathrm{Eu}=\mathrm{Eu}_{\mathrm{N}} /\left(0.5 \times \mathrm{Sm}_{\mathrm{N}}+0.5 \times \mathrm{Gd}_{\mathrm{N}}\right) ;$ Subscript $\mathrm{N}$ stands for upper continental crust normalized value.

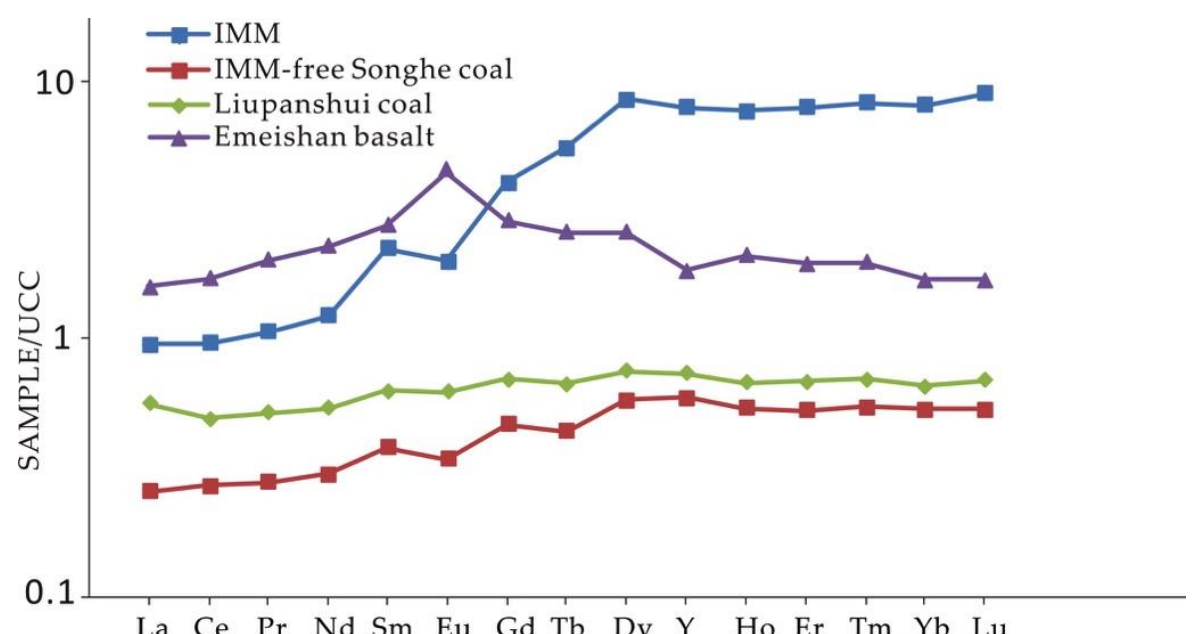

Figure 7. Rare earth elements and yttrium (REY) plots normalized by the average REY content of upper continental crust (UCC, Taylor and McLennan, 1985 [48]). 
IMM and IMM-free Songhe coal are both characterized by strongly negative Eu anomalies, with a $\delta_{\mathrm{Eu}}$ of 0.64 and 0.80 , respectively. However, Liupanshui coal shows a weak Eu anomaly $\left(\delta_{\mathrm{Eu}}=0.95\right)$. On the contrary, Emeishan basalt exhibits a pronounced positive Eu anomaly $\left(\delta_{\mathrm{Eu}}=1.55\right)$. As indicated by some researchers, Eu anomalies in coal are generally inherited from rocks in the sediment source region or are influenced by high-temperature hydrothermal fluids, but are not easily affected by weathering processes or the transportation of the source rock, e.g., [23,41,51,52]. Since the terrigenous input into the Late Permian sedimentary rocks and coal-forming environment was mainly derived from the Kangdian Upland, i.e., Emeishan large igneous province [24,42,47,53,54], the strong depletion of $\mathrm{Eu}$ in the IMM may be attributed to Eu loss in reducing settings during the peat accumulation and coalification process $[55,56]$, or the input of some other materials with negative Eu anomaly. For example, the No. 25 coal from the Guxu coalfield, with a strongly negative Eu anomaly, was related to the addition of terrigenous rocks characterized by felsic-intermediate compositions [23].

Bau [52] suggested that the $Y_{N}$ to $H_{N}$ ratio can be used as a $Y$ anomalies indicator. Relative to the UCC, $\mathrm{Y}_{\mathrm{N}} / \mathrm{Ho}_{\mathrm{N}}$ for the IMM and IMM-free Songhe coal are 1.03 and 1.10, respectively, displaying positive anomalies, while that of the Liupanshui coal and Emeishan basalt are 0.98 and 0.99, respectively, showing slightly negative anomalies (Table 2). Yttrium anomalies in coal may be attributed to previous geochemical processes within the sediment source rocks, the sedimentary environment, and hydrothermal fluids [41]. Therefore, like Eu depletion, which has been discussed above, the positive anomalies of $\mathrm{Y}$ in the IMM and the IMM-free Songhe coal cannot be simply attributed to the input of the weathering product of Emeishan basalt because the latter is characterized by a negative $\mathrm{Y}$ anomaly of 0.99 .

\subsection{Discussion}

\subsubsection{The IMM Origin}

The mineral veins are generally continuous, with only a few tiny disconnections or penetrations, which illustrates that the coal has not suffered serious deformation during or after the formation of IMM. The IMM only appears in the vitrain sublayers, rather than cutting through the coal seam or penetrating randomly into other coal petrologic sublayers. The IMM filling shows a feature of "sublayer confinement", or specifically, "vitrain-layer confinement". This is consistent with previous studies that suggested that bright coal lithotypes tend to develop more intensive fractures $[6,14]$. Therefore, these "vitrain confined" mineral veins are thus considered to have been generated locally in vitrain sublayers, instead of being introduced by factors like magmatic or hydrothermal inbreaking activities. In fact, if these veins were caused by the invasion of mineral-rich fluids, it cannot fill vitrain layers without damaging other coal matrixes. However, further study is still needed for the cause of the fractures.

In addition, the vitrinite maximum reflectance $\left(\mathrm{Ro}_{\max }\right)$ of the vitrain layer is close to that of the adjacent sublayers of the investigated coal sample (Table 1). This also indicates a low possibility of involvement of hydrothermal fluid or igneous activity during the formation of IMM. It seems that the vitrain layer might not have experienced accidental thermal alteration.

A REY geochemistry study shows that the IMM displays higher REY abundance and a distinct distribution pattern when compared to the local Late Permian coals and the sediment source rock, Emeishan basalt. The IMM is characterized by a pronounced left incline REY distribution, a strongly negative $\delta_{\mathrm{Eu}}$ value and a slightly positive $\mathrm{Y}_{\mathrm{N}} / \mathrm{Ho}_{\mathrm{N}}$ value, which are distinct from Emeishan basalt. Generally, the REY in carbonate rocks is relatively low, but Sun [57] studied the super high concentration (up to $31,000 \mu \mathrm{g} / \mathrm{g}$ ) of rare earth elements and strongly negative Ce and $\mathrm{Eu}$ in the carbonate rock weathering profiles from Guizhou, SW China, and found that carbonate rock can supply enough rare earth elements during weathering - that is, after the solution of carbonate materials, the alkali barrier may be an important factor that causes rare earth enrichment. Thus, the enrichment of REY in IMM of the studied sample may be derived from overlying carbonates via dissolution and groundwater leaching. 
Since the IMM is dominated by calcite, it is supposed that the formation of IMM is primarily due to $\mathrm{Ca}^{2+}$ precipitation and crystallization of calcite in the fractures. In the recrystallization process, heavy rare earth ions have radiuses that are slightly smaller than calcium ions; thus, they can enter the calcite crystal structure more easily than the light rare earth ions [58], leading to a pronounced left incline pattern of the REY of the IMM. Thus, this REY fractional process may also influence the migration of individual rare earth elements, partly resulting in the strong Eu anomaly of the IMM. However, the effect of calcite crystallization and REY-Ca isomorphous replacement on Eu and Ce anomalies is still not clear.

As discussed above, it is unlikely that the material source of the IMM was caused by epigenetic hydrothermal-fluids or magmatic intrusions. Therefore, the IMM is probably of normal sedimentary genesis (for example, precipitation of calcium rich groundwater), followed by a REY differentiation during the peat accumulation and coalification process, or with certain additions of terrigenous materials such as silicic volcanic rock detrital [47] or felsic or felsic-intermediate rocks [23].

\subsubsection{The Formation of the Fractures}

The fractures only occur in the vitrain layers, and patterns of which are distinctly different from those of samples that have been affected by hydrothermal alteration with mineral vein intrusion, e.g., [59]. Therefore, prior to being infilled with mineral matters, these "vitrain confined" fractures were probably generated within the vitrain sublayers during the peatifcation or/and coalification process. A possible explanation is that the fractures probably resulted from tissues of the coal-forming plant. This is because, macroscopically, the morphological characteristic of the fractures exhibit leaf vein-like or bark-like patterns (Figure 3). A previous study showed that, in southwestern China, Late Permian was the age of flourish for Cathaysian flora. As typical representatives of Cathaysian flora, Gigantopterides, Lepidodendron, as well as lycopod dominated-Sigillaria [60], were found to be characterized by very broad fern leaves, diadromous and big caudexes [4,6,31]. Our field investigation confirmed that plant fossil fragments (leaves, barks, etc.) are relatively rich in Late Permian coal-bearing strata in the Liupanshui coalfield. For example, regular rhombus imprints may have resulted from plant fossils, probably bark imprints (Figure 8), and a thin layer of net-like deposition on the surface of a fossil plant-rich carbonaceous mudstone of the Late Permian coal-bearing strata (Figure 9). Therefore, after the breakdown of the coal-forming plant, it was the slower decay and following vacation of some plant tissues that lead to massive interspaces, which are now fractures. However, it was found that the depth of these fractures would change with the thickness of the vitrain layers, which is difficult to explain with the idea of plant tissue genesis.
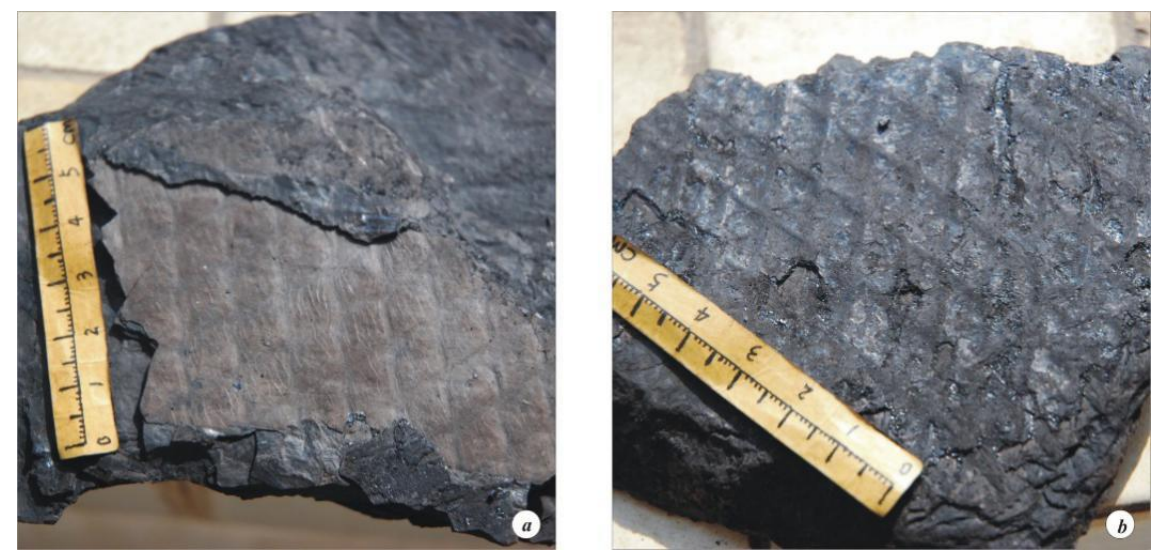

Figure 8. Regular rhombus imprints on the bedding surface of two parts of a Late Permian coal sample from the Liupanshui coalfield: (a) the part above the bedding surface; (b) the part below the bedding surface. 


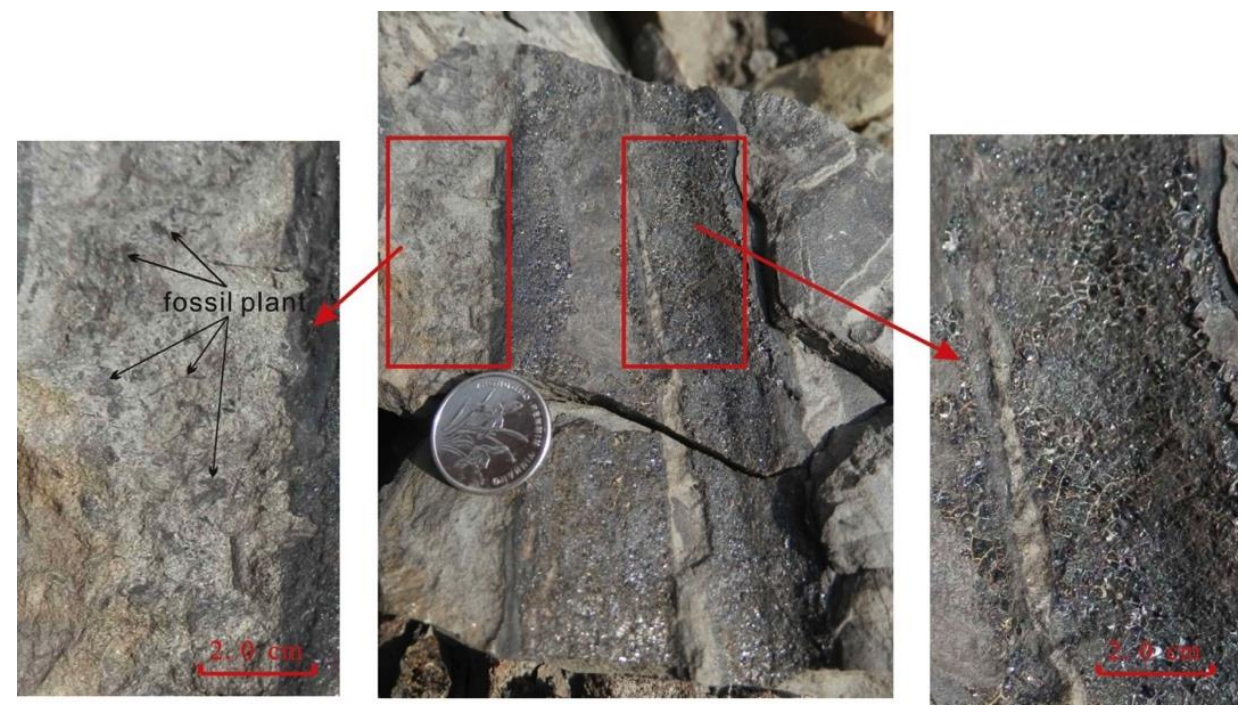

Figure 9. Fossil barks in a fossil plant-rich carbonaceous mudstone, Liupanshui coalfield.

Another possible cause is that the fractures were of autogenetic genesis during the peatifcation or/and coalification process. As mentioned above, coals with this unique fracture are of banded structure, i.e., dark coal bands (vitrain layers) and light coal bands (clarain, durain and fusain layers), which appear alternately. Fractures only appear in the vitrain layers, implying that the vitrain layers are composed of different peat biomass from clarain, durain and fusain layers. This can be partly confirmed by the fact that the vitrain layer has a much higher volatile (38.50\%) than that of the other parts $(26.11 \%)$ (Table 2). In fact, a larger proportion of volatile matter means that the vitrain layer is prone to shrinking during the diagenesis process, which induces the fractures. However, the genesis of dark and light coal bands is confronted with contrasting explanations such as peat-forming plant community, degrees of plant decomposition, and wet/dry conditions of peat-accumulation environments [4]. Thus, for the vitrain layer, the relationship between the biomass nature and generation of fractures still needs further study.

\subsubsection{The Effect of the Fractures on CBM Behaviors}

As discussed above, fractures in the coal are important for the investigation of the CBM occurrence and flow behavior and is crucial for both safety production and gas utilization in the coal mining industry [9-11]. The coal sample studied in this paper can be characterized by a banded structure with intensively fractured vitrain layers. This banded and fractured coal structure may have a certain influence on CBM flow, which is useful for CBM migration behavior prediction in coal seams. First, the fractured vitrain layers appear alternately and repetitively along the coal seam profile, which makes the coal seam more fragmented and provides more space for the flow of CBM. Secondly, the extending direction of the sublayers (including the fractured vitrain layer) of the banded coal is generally consistent with that of the entire coal seam, which creates a greater chance for CBM to flow in the extending direction of the coal seam.

In addition, our previous field investigation suggested that coals with this type of special structure can be found in coalmines, mainly from the boundary region of Western Guizhou Province, especially the western part of Panzhou and Shuicheng county [43], where the river dominates the upper delta plain and developed well during the coal-forming period (Late Permian) (Figure 1). The discovery of this lends credence to the idea that the geographic distribution of this fractured structure coal may be related to the coal-forming sedimentary environment of the studied region. Due to factors like climate change, the frequent variation of the phreatic water tables of a coal-forming delta plain mire (constantly changing between wet and dry) may result in different degrees of degradation of the organic material in the peat [47], which in turn influence the gelatinization and periodic production of the vitrain layer, 
which has the highest degree of gelatinization and intensive fractures. Thus, we speculate that it is the river-dominated upper delta plain that might have provided favorable conditions for the formation of the special coal structure. This provides a new perspective for the evaluation of the CBM through the recognition of peat depositional environments. However, there are many important considerations in the analysis and interpretation of indicators for CBM evaluation, the potential connection between the sedimentary environment and CBM occurrence and flow characteristics is not yet clear and further investigation is needed in the future.

\section{Conclusions}

(1) A Late Permian coal from Southwestern China was found to have a banded structure with intensively fractured vitrain sublayers. Those fractures exhibit patterns of leaf veins, roots or barks and were filled with massive mineral matters (mainly calcite as for No.3 coal from Songhe coal, Liupanshui coalfeld).

(2) Study on coal petrology, coal quality, as well as mineralogy and REY geochemistry of the IMM show that the fractures probably resulted from tissues of coal-forming plant or of autogenetic genesis (for example shrinkage) during the peatifcation or/and coalification process, while the IMM in those fractures probably resulted from precipitation of the calcium rich groundwater and certain addition of terrigenous materials.

(3) The banded structure and the intensive fractures only develop in the vitrain sublayers. This provides a potential path for CBM flow and implies that the flow direction of the CBM may be confined by the attitude of the coal seam. This, with respect to Late Permian coal from the Western Guizhou border, suggests a possible relationship between CBM migration and specific coal-forming paleogeography (such as the river dominated upper delta plain), although more evidence is necessary.

Author Contributions: Conceptualization, R.Y. and Q.Z.; data curation, W.C.; funding acquisition, R.Y.; investigation and methodology, W.C.; project administration, W.C. and R.Y.; writing-original draft, W.C.; writing-review and editing, Q.Z. All authors have read and agreed to the published version of the manuscript.

Funding: This study was supported by National Natural Science Foundation (41802190) and Guizhou Provincial Young Scientific and Technologic Talent Project (Qian Jiao He KY-[2016]-128).

Conflicts of Interest: The authors declare no conflict of interest.

\section{References}

1. Suárez-Ruiz, I.; Flores, D.; Filho, J.G.M.; Hackley, P.C. Review and update of the applications of organic petrology: Part 1, geological applications. Int. J. Coal Geol. 2012, 99, 54-112. [CrossRef]

2. Ward, C.R. Analysis, origin and significance of mineral matter in coal: An updated review. Int. J. Coal Geol. 2016, 165, 1-27. [CrossRef]

3. Finkelman, R.B.; Dai, S.; French, D. The importance of minerals in coal as the hosts of chemical elements: A review. Int. J. Coal Geol. 2019, 212, 103251. [CrossRef]

4. Dai, S.; Bechtel, A.; Eble, C.F.; Flores, R.M.; French, D.; Graham, I.T.; Hood, M.M.; Hower, J.C.; Korasidis, V.A.; Moore, T.A.; et al. Recognition of peat depositional environments in coal: A review. Int. J. Coal Geol. 2020, 219, 103383. [CrossRef]

5. Busse, J.; De Dreuzy, J.; Torres, S.A.G.; Bringemeier, D.; Scheuermann, A. Image processing based characterisation of coal cleat networks. Int. J. Coal Geol. 2017, 169, 1-21. [CrossRef]

6. Han, D. China Coal Petrology; China University of Mining and Technology Press: Beijing, China, 1996; Chapter 2; pp. 26-93. (In Chinese)

7. Laubach, S.E.; Marrett, R.A.; Olson, J.E.; Scott, A.R. Characteristic and origins of coal cleat. Int. J. Coal Geol. 1998, 35, 175-208. [CrossRef]

8. Flores, R.M. Coalbed methane: From hazard to resource. Int. J. Coal Geol. 1998, 35, 3-26. [CrossRef] 
9. Pattison, C.I.; Fielding, C.R.; McWatters, R.H.; Hamilton, L.H. Nature and Origin of Fractures in Permian Coals from the Bowen Basin, Queensland, Australia. In Special Publications-Coal Bed Methane and Coal Geology; Gayer, R., Harris, I., Eds.; Geological Society: London, UK, 1996; pp. 133-150.

10. Rodrigues, C.F.A.; Laiginhas, C.; Fernandes, M.; De Sousa, M.J.L.; Dinis, M.A.P. The coal cleat system: A new approach to its study. J. Rock Mech. Geotech. Eng. 2014, 6, 208-218. [CrossRef]

11. Mostaghimi, P.; Armstrong, R.T.; Gerami, A.; Hu, Y.; Jing, Y.; Kamali, F.; Liu, M.; Liu, Z.; Lu, X.; Ramandi, H.L.; et al. Cleat-scale characterisation of coal: An overview. J. Nat. Gas Sci. Eng. 2017, 39, 143-160. [CrossRef]

12. Ministry of Natural Resources PRC. China Mineral Resources 2019; Geological Publishing House: Beijing, China, 2019; pp. 1-64.

13. Shao, Z.J.; Ren, W.Z.; Chen, J.L. Coal Geology; China Coal Industry Publishing House: Beijing, China, 1993; p. 27. (In Chinese)

14. Su, X.; Feng, Y.; Chen, J. The classification of fractures in coal. Coal Geol. Explor. 2002, 30, 21-24, (In Chinese with English Abstract).

15. Dawson, G.K.; Esterle, J.S. Controls on coal cleat spacing. Int. J. Coal Geol. 2010, 82, 213-218. [CrossRef]

16. Cheng, Q.Y.; Huang, B.X.; Li, Z.H. Research status of pore and crack in coal. Coal Eng. 2011, 12, 91-93, (In Chinese with English Abstract).

17. Jing, Y.; Armstrong, R.T.; Ramandi, H.L.; Mostaghimi, P. Coal cleat reconstruction using micro-computed tomography imaging. Fuel 2016, 181, 286-299. [CrossRef]

18. Weniger, S.; Weniger, P.; Littke, R. Characterizing coal cleats from optical measurements for CBM evaluation. Int. J. Coal Geol. 2016, 154, 176-192. [CrossRef]

19. Su, X.; Feng, Y.; Chen, J.; Pan, J. The characteristics and origins of cleat in coal from Western North China. Int. J. Coal Geol. 2001, 47, 51-62. [CrossRef]

20. Spears, D.; Caswell, S. Mineral matter in coals: Cleat minerals and their origin in some coals from the english midlands. Int. J. Coal Geol. 1986, 6, 107-125. [CrossRef]

21. Dai, S.; Wang, P.; Ward, C.R.; Tang, Y.; Song, X.; Jiang, J.; Hower, J.C.; Li, T.; Seredin, V.V.; Wagner, N.; et al. Elemental and mineralogical anomalies in the coal-hosted Ge ore deposit of Lincang, Yunnan, southwestern China: Key role of N2-CO2-mixed hydrothermal solutions. Int. J. Coal Geol. 2015, 152, 19-46. [CrossRef]

22. Dai, S.; Yang, J.; Ward, C.R.; Hower, J.C.; Liu, H.; Garrison, T.; French, D.; O'Keefe, J.M. Geochemical and mineralogical evidence for a coal-hosted uranium deposit in the Yili Basin, Xinjiang, northwestern China. Ore Geol. Rev. 2015, 70, 1-30. [CrossRef]

23. Dai, S.; Liu, J.; Ward, C.R.; Hower, J.C.; French, D.; Jia, S.; Hood, M.M.; Garrison, T. Mineralogical and geochemical compositions of Late Permian coals and host rocks from the Guxu Coalfield, Sichuan Province, China, with emphasis on enrichment of rare metals. Int. J. Coal Geol. 2016, 166, 71-95. [CrossRef]

24. Dai, S.; Xie, P.; Jia, S.; Ward, C.R.; Hower, J.C.; Yan, X.; French, D. Enrichment of U-Re-V-Cr-Se and rare earth elements in the Late Permian coals of the Moxinpo Coalfeld, Chongqing, China: Genetic implications from geochemical and mineralogical data. Ore Geol. Rev. 2017, 80, 1-17. [CrossRef]

25. Department of Natural Resources of Guizhou Province. Natural Resources Statistical Bulletin of Guizhou; Department of Natural Resources of Guizhou Province: Guiyang, China, 2019; pp. 1-52. Available online: http://zrzy.guizhou.gov.cn/ (accessed on 2 July 2019). (In Chinese)

26. Liu, G. Permo-Carboniferous paleogeography and coal accumulation and their tectonic control in the North and South China continental plates. Int. J. Coal Geol. 1990, 16, 73-117. [CrossRef]

27. Wang, H.; Shao, L.; Hao, L.; Zhang, P.; Glasspool, I.J.; Wheeley, J.R.; Wignall, P.B.; Yi, T.; Zhang, M.; Hilton, J. Sedimentary and sequence stratigraphy of the Lopingian (Late Permian) coal measures in southwestern China. Int. J. Coal Geol. 2011, 85, 168-183. [CrossRef]

28. Chen, W.; Liu, J.; Wang, Z.; Zheng, Q. Study of lithofacies paleogeography during the Permian Emeishan basalt explosion in Guizhou Province. J. Palaeogeogr. 2003, 5, 17-28, (In Chinese with English Abstract).

29. Dai, S.; Ren, D.; Tang, Y.; Yue, M.; Hao, L. Concentration and distribution of elements in Late Permian coals from western Guizhou Province, China. Int. J. Coal Geol. 2005, 61, 119-137. [CrossRef]

30. Shao, L.; Zhang, P.; Ren, D.; Lei, J. Late Permian coal-bearing carbonate successions in southern China: Coal accumulation on carbonate platforms. Int. J. Coal Geol. 1998, 37, 235-256. [CrossRef]

31. Guizhou Bureau of Geology and Mineral Exploration. Coal Geology for Late Permian Coals from Guizhou Province (II); unpublished report; 1987; Chapter 6 to 8. (In Chinese) 
32. GB/T 212-2008. Proximate Analysis of Coal. (GB: National Standard of P.R. China). Available online: http://www.cssn.net.cn (accessed on 14 May 2020). (In Chinese).

33. GB/T 214-2007. Determination of Total Sulfur in Coal. (GB: National Standard of P.R. China). Available online: http://www.cssn.net.cn (accessed on 14 May 2020). (In Chinese).

34. GB/T 6948-2008. Method of Determining Microscopically the Reflectance of Vitrinite in Coal. (GB: National Standard of P.R. China). Available online: http://www.cssn.net.cn (accessed on 14 May 2020). (In Chinese).

35. GB/T 16773-2008. Method of Preparing Coal Samples for the Coal Petrographic Analysis. (GB: National Standard of P.R. China). Available online: http://www.cssn.net.cn (accessed on 14 May 2020). (In Chinese).

36. Schatzel, S.J.; Stewart, B.W. Rare earth element sources and modification in the Lower Kittanning coal bed, Pennsylvania: Implications for the origin of coal mineral matter and rare earth element exposure in underground mines. Int. J. Coal Geol. 2003, 54, 223-251. [CrossRef]

37. Wang, X.; Jiao, Y.; Wu, L.; Rong, H.; Wang, X.; Song, J. Rare earth element geochemistry and fractionation in Jurassic coal from Dongsheng-Shenmu area, Ordos Basin. Fuel 2014, 136, 233-239. [CrossRef]

38. Hower, J.C.; Eble, C.F.; Dai, S.; Belkin, H. Distribution of rare earth elements in eastern Kentucky coals: Indicators of multiple modes of enrichment? Int. J. Coal Geol. 2016, 160-161, 73-81. [CrossRef]

39. Seredin, V.V.; Finkelman, R.B. Metalliferous coals: A review of the main genetic and geochemical types. Int. J. Coal Geol. 2008, 76, 253-289. [CrossRef]

40. Seredin, V.V.; Dai, S. Coal deposits as potential alternative sources for lanthanides and yttrium. Int. J. Coal Geol. 2012, 94, 67-93. [CrossRef]

41. Dai, S.; Graham, I.T.; Ward, C.R. A review of anomalous rare earth elements and yttrium in coal. Int. J. Coal Geol. 2016, 159, 82-95. [CrossRef]

42. Liu, J.; Song, H.; Dai, S.; Nechaev, V.P.; Graham, I.T.; French, D.; Nechaeva, E.V. Mineralization of REE-Y-Nb-Ta-Zr-Hf in Wuchiapingian coals from the Liupanshui Coalfeld, Guizhou, southwestern China: Geochemical evidence for terrigenous input. Ore Geol. Rev. 2019, 115, 103190. [CrossRef]

43. Cheng, W.; Yang, R.; Zhang, Q. Distribution Characteristics, Enrichment Genesis and Cleaning Potentials of Trace Elements in Late Permian Coal from Liupanshui Coalfield, SW China; Guizhou Science and Technology Publishing House Co., Ltd.: Guiyang, China, 2015; pp. 94-178.

44. Liao, B. Study of Petrology and Geochemistry of the Permian Alkaline Basalts in Guizhou Province. Ph.D. Thesis, China University of Geosciences, Wuhan, China, 2013. (In Chinese with English Abstract).

45. Yang, R.; Liu, L.; Wei, H.-R.; Cui, Y.-C.; Cheng, W. Geochemical characteristics of Guizhou Permian coal measure strata and analysis of the control factors. J. Coal Sci. Eng. (China) 2011, 17, 55-68. [CrossRef]

46. Yu, X.; Yang, J.; Liu, J.; Du, Y.; Chai, R. Provenance of the Late Permian Longtan Formation in SW Guizhou Province and Implication for Reconstruction of Regional Sedimentation and Paleogeography. Acta Geol. Sin. 2017, 91, 1374-1385, (In Chinese with English Abstract).

47. Deng, X.-S.; Yang, J.; Cawood, P.A.; Wang, X.-C.; Du, Y.; Huang, Y.; Lu, S.-F.; He, B. Detrital record of late-stage silicic volcanism in the Emeishan large igneous province. Gondwana Res. 2020, 79, 197-208. [CrossRef]

48. Taylor, S.R.; McLennan, S.H. The Continental Crust: Its Composition and Evolution; Blackwell: Oxford, UK, 1985; p. 312.

49. Li, B.; Zhuang, X.; Li, J.; Querol, X.; Font, O.; Moreno, N.; Palmerola, N.M. Geological controls on mineralogy and geochemistry of the Late Permian coals in the Liulong Mine of the Liuzhi Coalfield, Guizhou Province, Southwest China. Int. J. Coal Geol. 2016, 154, 1-15. [CrossRef]

50. Göb, S.; Loges, A.; Nolde, N.; Bau, M.; Jacob, D.E.; Markl, G. Major and trace element compositions (including REE) of mineral, thermal, mine and surface waters in SW Germany and implications for water-rock interaction. Appl. Geochem. 2013, 33, 127-152. [CrossRef]

51. Eskenazy, G.M. Rare earth elements in a sampled coal from the Pirin deposit, Bulgaria. Int. J. Coal Geol. 1987, 7, 301-314. [CrossRef]

52. Bau, M.; Schmidt, K.; Koschinsky, A.; Hein, J.; Kuhn, T.; Usui, A. Discriminating between different genetic types of marine ferro-manganese crusts and nodules based on rare earth elements and yttrium. Chem. Geol. 2014, 381, 1-9. [CrossRef]

53. Xu, L.; Lin, Y.; Shen, W.; Qi, L.; Xie, L.; Ouyang, Z. Platinum-group elements of the Meishan Permian-Triassic boundary section: Evidence for flood basaltic volcanism. Chem. Geol. 2007, 246, 55-64. [CrossRef] 
54. Dai, S.; Ward, C.R.; Graham, I.T.; French, D.; Hower, J.C.; Zhao, L.; Wang, X. Altered volcanic ashes in coal and coal-bearing sequences: A review of their nature and significance. Earth-Science Rev. 2017, 175, 44-74. [CrossRef]

55. Wang, Z.; Yu, X.; Zhao, Z. Rare Earth Element Geochemistry; Science Press: Beijing, China, 1989; pp. 1-541. (In Chinese)

56. Bau, M. Rare-earth element mobility during hydrothermal and metamorphic fluid-rock interaction and the significance of the oxidation state of europium. Chem. Geol. 1991, 93, 219-230. [CrossRef]

57. Sun, C.; Wang, S.; Ji, H. Formation mechanism of the superhigh concentration of REE and the strong negative Ce anomalies in the carbonate rock weathering profiles in Guizhou Province, China. Geochimica 2002, 31, 119-128, (In Chinese with English Abstract).

58. Voigt, M.; Mavromatis, V.; Oelkers, E.H. The experimental determination of REE partition coefficients in the water-calcite system. Chem. Geol. 2017, 462, 30-43. [CrossRef]

59. Dai, S.; Chou, C.-L.; Yue, M.; Luo, K.; Ren, D. Mineralogy and geochemistry of a Late Permian coal in the Dafang Coalfield, Guizhou, China: Influence from siliceous and iron-rich calcic hydrothermal fluids. Int. J. Coal Geol. 2005, 61, 241-258. [CrossRef]

60. Wang, X.; Zheng, X.-T. Reconsiderations on two characters of early angiosperm Archaefructus. Palaeoworld 2012, 21, 193-201. [CrossRef]

(C) 2020 by the authors. Licensee MDPI, Basel, Switzerland. This article is an open access article distributed under the terms and conditions of the Creative Commons Attribution (CC BY) license (http://creativecommons.org/licenses/by/4.0/). 